\title{
Economic premiums associated with Mycobacterium avium ssp. paratuberculosis-negative replacement purchases in major dairy-producing regions
}

\author{
Philip Rasmussen, ${ }^{1 *} \odot$ Herman W. Barkema, ${ }^{2} \odot$ Eugene Beaulieu, ${ }^{3} \odot$ Steve Mason, ${ }^{2} \odot$ and David C. Hall ${ }^{4} \odot$ \\ ${ }^{1}$ Section of Epidemiology, University of Zürich, Zürich, Zürich, Switzerland, CH 8,057 \\ ${ }^{2}$ Department of Production Animal Health, University of Calgary, Calgary, AB, Canada, T2N 4N1 \\ ${ }^{3}$ Department of Economics, University of Calgary, Calgary, AB, Canada, T2N 1N4 \\ ${ }^{4}$ Department of Ecosystem and Public Health, University of Calgary, Calgary, AB, Canada, T2N 4N1
}

\section{ABSTRACT}

Johne's disease, or paratuberculosis, is an infectious disorder of the intestines that can affect domestic and wild ruminants that is caused by an infection with Mycobacterium avium ssp. paratuberculosis (MAP). Although the economic losses due to Johne's disease in dairy cattle herds and the benefits and costs of various potential control practices have been estimated before, little is known about the economic value of purchasing MAP-negative dairy replacements in major dairy-producing regions. This study used Markov Chain Monte Carlo simulation techniques to compare 2 sets of MAP-negative and MAP-positive herds across a comprehensive selection of regions: herds purchasing MAP-negative replacement animals and herds purchasing replacement animals with unknown MAP infection status. The economic benefits per MAP-negative replacement purchased were then estimated over a 10-yr horizon, and the additional value of MAP-negative replacements when compared with unknown status replacements were calculated as a percentage premium of the average aggregated dairy replacement price in each region. An average benefit of US $\$ 76$ per MAPnegative replacement purchase was estimated in major dairy-producing regions, equivalent to a premium of $13 \%$, with higher premiums in regions characterized by below-average replacement prices and on-average farmgate prices. It was also estimated that the greatest benefits from MAP-negative replacement purchases are associated with MAP-negative herds that successfully remain uninfected.

Key words: paratuberculosis, dairy, replacement, economic premium

Received August 31, 2021.

Accepted December 17, 2021.

*Corresponding author: philip.rasmussen@uzh.ch

\section{INTRODUCTION}

Johne's disease (JD), or paratuberculosis, is an infectious disorder of the intestines that can affect domestic and wild ruminants including cattle (Fecteau and Whitlock, 2010). The disease is caused by an infection with Mycobacterium avium ssp. paratuberculosis (MAP), a resistant bacterial organism that can persist for extended periods outside of its host environment (Manning and Collins, 2001; Whittington et al., 2004; Donaghy et al., 2009). As its clinical signs progress, JD in dairy cattle can lead to diarrhea, lethargy, and reduced milk production, and eventually hypoproteinemia, severe emaciation, and potentially death. These animal health burdens are passed on to dairy producers in the form of substantial economic losses (Garcia and Shalloo, 2015), with reduced milk production (Lombard et al., 2005; McAloon et al., 2016), reduced slaughter value (Benedictus et al., 1985; Kudahl and Nielsen, 2009; Raizman et al., 2009), and premature culling (Ott et al., 1999; Shephard et al., 2016) as primary sources. Annual economic losses per cow among MAP-infected dairy herds in the United States have been estimated at US $\$ 21$ (Ott et al., 1999), US $\$ 35$ (Groenendaal et al., 2002), and up to US $\$ 79$ (Pillars et al., 2009). Annual losses among MAP-infected herds in Canada have been estimated at CA $\$ 49$ per cow (Tiwari et al., 2008 ) and between US\$35 and US\$57 per cow (Rasmussen et al., 2021a), whereas annual losses in major dairy-producing regions have been estimated at US $\$ 33$ per cow, or approximately $1 \%$ of gross milk revenue (Rasmussen et al., 2021a). The herd-level prevalence of MAP infection likely exceeds $50 \%$ in most countries with significant dairy industries (Barkema et al., 2018), and there is a need to comprehensively estimate the value of JD control to dairy producers. Although estimates exist for the effectiveness and economic benefits of various potential control practices (Groenendaal et al., 2002; Groenendaal et al., 2003; Kudahl et al., 2007; Groenendaal et al., 2015; Kirkeby et al., 2016; Smith 
et al., 2017; Rasmussen et al., 2021b), little is known about the economic benefits associated with purchasing MAP-negative replacements. Accordingly, this study used the Markovian framework established in Rasmussen et al. (2021a) to estimate economic premiums associated with MAP-negative replacement purchases across a comprehensive selection of dairy-producing regions over a 10-yr horizon.

\section{MATERIALS AND METHODS}

Two sets of herds were analyzed in each major dairyproducing region: (1) MAP-negative herds purchasing replacements with unknown MAP infection status were compared with MAP-negative herds purchasing MAPnegative replacements, and (2) MAP-positive herds purchasing replacements with unknown MAP infection status were compared with MAP-positive herds purchasing MAP-negative replacements. The economic benefits associated with MAP-negative replacement purchases were estimated based on an assumed herdlevel MAP infection prevalence of $50 \%$ and a withinherd prevalence of MAP infection of $10 \%$ within infected herds. The expected value of those benefits across both MAP-negative and MAP-positive herds was then calculated to estimate the premiums associated with MAP-negative replacements as a percentage of regionspecific aggregated replacement prices.

\section{Within-Herd Prevalence and Sources of Losses}

The spread of MAP infection within dairy herds was modeled over a 10-yr horizon using a MAP-positive herd model with a separately modeled replacement pool within the Markovian framework established in Rasmussen et al. (2021a). Within this framework, animals can remain MAP negative and continue aging, become infected and continue aging, or be culled. Once an animal becomes MAP positive, it can either be culled or its stage of infection can progress, regress, or remain the same, with each stage associated with a different risk of being culled. Each stage also has some nonshedding, lightly shedding, moderately shedding, and heavily shedding states within it, and the MAP burden on the herd, or the infection pressure on animals in the herd, is determined by the number and degree of shedding animals in the herd in each period. For MAP-negative animals, the probability of being culled remains the steady-state MAP-negative value according to their age category, as determined by the initial age structure and model initialization over a 50yr, 10,000-iteration simulation. The baseline herd came to a steady state with the following characteristics: an annual cow-culling rate of $27 \%$ (equivalent to a turn- over rate of 27 cows per 100 cow-years), a young-stock percentage (including calves $<1$ yr of age) of $48 \%$, and for a 100-cow herd, 1.36 cows and 3.07 young-stock between 1 and 2 yr of age being purchased each year. These values are comparable to those observed in Canadian herds, which have an average cow-culling rate between 26\% and 33\% (OMAFRA, 2020), an average young-stock percentage of $48 \%$ (StatCan, 2019b), and purchase an average of 1.37 cows and 3.09 young-stock between 1 and 2 yr of age per 100 cows per year (Van Biert, 2019).

For MAP-positive animals, the probability of being culled depends on the stage of their infection, increasing with severity. For each economic region, 2 sets of models are compared. For the set with replacements of unknown MAP infection status, purchased replacements entered the herd from the replacement pool with a MAP-infection prevalence based on the mean withinherd prevalence and the mean herd-level prevalence in that region. It was assumed that all regions had an initial within-herd MAP infection prevalence of $10 \%$ and a herd-level prevalence of $50 \%$, resulting in a regional cow-level prevalence of $5 \%$ among replacement purchases. For the set with MAP-negative replacements, the regional cow-level prevalence is assumed to be $0 \%$. The 10,000-iteration Monte Carlo simulations were then used to estimate the changes in herd structure, MAP infection prevalence, and the 3 sources of losses associated with JD in dairy cattle in the model: premature culls, MAP-positive animals salvaged, and MAP-positive cows with reduced milk production. The benefits in terms of reduced losses were then compared across the replacement with unknown MAP infection status and MAP-negative replacement sets to estimate the economic benefits associated with MAP-negative replacements.

\section{Economic Premiums}

The mean benefits associated with MAP-negative replacement purchases compared with replacement purchases with unknown MAP infection status over the 10-yr horizon were divided by the total number of replacements purchased across all replacement age categories (12 to 15,15 to 18,18 to 21 , and 21 to 24 mo of age) to obtain an estimate of the economic benefits per replacement purchased. The estimated economic benefits per replacement purchased were then divided by the average aggregated replacement price across all replacement age categories to obtain an estimate of the percent economic premium per MAP-negative replacement purchased. This was repeated in both MAP-negative and MAP-positive herds across a comprehensive selection of major dairy-producing regions using region- 
specific economic variables (obtained from Rasmussen et al., 2021a and summarized in Table 1 and Table 2), assuming a mean within-herd MAP infection prevalence of $10 \%$ and mean herd-level MAP prevalence of $50 \%$. Due to the unique market conditions that arise due to supply management in Canada (fixed annual output and above-average farm-gate prices for milk), this comparison was repeated a second time for Canada with production losses instead measured as an increase in the variable costs associated with milk production (labor, veterinary fees, bedding, feed, and so on).

\section{Sensitivity Analyses}

Finally, the sensitivity of estimated economic premiums associated with MAP-negative replacements to variations in the values of the model's input variables was tested using 10,000-iteration Monte Carlo simulations. Average MAP-negative and MAP-positive herds were selected based on the average values of all regions modeled, along with an initial mean value of $10 \%$ within-herd prevalence in MAP-positive herds and 50\% herd-level prevalence. As described in Rasmussen et al. (2021a), all variables were assumed to have normal distributions with standard deviations of $10 \%$ of their mean values, except for within-herd and regional cowlevel prevalence, which were assumed to have normal distributions and standard deviations equal to $20 \%$ of their mean values. Although these assumed standard deviations may seem constrictive, data required to determine their true values were unavailable and the selected standard deviations capture a wide range of input values without destabilizing the simulations and their results.

\section{RESULTS}

\section{Effect of MAP-Negative Replacements on Herd Structure}

For simplicity, generic MAP-negative and MAPpositive herds with no region-specific economic variables were used to describe the behavior of the model with the assumptions of an initial within-herd MAP infection prevalence of $10 \%$, a herd-level MAP infection prevalence of $50 \%$, and a resulting regional cow-level MAP infection prevalence of $5 \%$ among animals in the replacement pool (Table 3). In MAP-negative herds with MAP-negative replacements, no changes in the sources of losses were associated with MAP infection in dairy cattle as within-herd prevalence remained at $0 \%$. However, with purchased replacements of unknown MAP infection status entering the herd from the regional replacement pool, mean within-herd prevalence increased from $0 \%$ in yr 0 to $5.32 \%$ (approximately the regional cow-level prevalence) in yr 10. Premature culls due to MAP as a percentage of total culls increased from 0 to $0.6 \%$, MAP-positive culls as a percentage of total culls increased from 0 to $3.35 \%$, and forgone production increased from 0 to $0.31 \%$ over the 10 -yr horizon. In MAP-positive herds with MAP-negative replacements, within-herd prevalence increased from its initial value of $9.99 \%$ in yr 0 to $16.53 \%$ in yr 10 . Premature culls as a percentage of total culls increased from 1.56 to $3.61 \%$, MAP-positive culls as a percentage of total culls increased from 6.90 to $11.11 \%$, and forgone production increased from 0.60 to $0.98 \%$. With replacements with unknown MAP infection status instead, within-herd prevalence approximately doubled to $19.57 \%$ (a $30 \%$ increase in within-herd prevalence relative to its initial value when compared with the MAP-negative replacement scenario). Similar increases (in terms of relative magnitude) to the MAP-negative replacement scenarios were observed in premature culls, MAP-positive culls, and forgone production.

\section{Economic Premiums}

Average aggregated replacement prices, benefits per replacement associated with MAP-negative purchased replacements, and premiums as a percentage of aggregated replacement prices across major dairy-producing regions are presented in Table 4. In MAP-negative herds, 10-yr average benefits per MAP-negative replacement purchase ranged from US $\$ 21$ in Brazil to US\$208 in Japan, with a revenue-weighted average of US $\$ 80$. These benefits, when measured as a percentage of the region-specific aggregated replacement price for replacements of all ages, resulted in economic premiums associated with MAP-negative replacement purchases ranging from $7 \%$ in Ireland to $26 \%$ in Poland, with a revenue-weighted average of $14 \%$. In MAP-positive herds, aggregate replacement prices were higher than in MAP-negative herds as relatively costly mature cows, which were assumed to be costlier to replace than immature animals, remained in the herd for shorter periods. Benefits per MAP-negative replacement and economic premiums associated with those replacements were also lower; benefits ranged from US\$19 in Brazil to US\$188 in Japan with a revenue-weighted average of US $\$ 73$, and premiums ranged from $7 \%$ in Ireland to $20 \%$ in Poland, with a revenue-weighted average of $12 \%$. The expected value of aggregated replacement prices, economic benefits, and economic premiums across major dairy-producing regions based on $50 \%$ of herds being MAP-negative and $50 \%$ of herds being MAP-positive are presented in Table 5. Benefits ranged from US $\$ 20$ in Brazil to US\$198 in Japan with a revenue-weighted 
average of US\$76, whereas premiums ranged from $7 \%$ in Ireland to $23 \%$ in Poland with a revenue-weighted average of $13 \%$.
Canadian estimates for MAP-negative herds under the both the assumptions of variable annual production used in the estimates for other major dairy-producing

Table 1. Key dairy sector characteristics for various dairy-producing regions, in order of decreasing annual production, used in the estimation

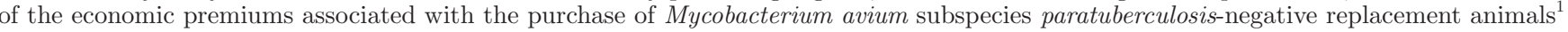

\begin{tabular}{|c|c|c|c|c|}
\hline Region & $\begin{array}{c}\text { Annual production }{ }^{2} \\
\text { ('000 Mt) }\end{array}$ & $\begin{array}{c}\text { Annual production }{ }^{3} \\
(\mathrm{~kg} / \text { cow })\end{array}$ & $\begin{array}{c}\text { Dairy cattle } \\
\text { ('000 head) }\end{array}$ & $\begin{array}{c}\text { Farm-gate price } \\
\text { (US\$/100 kg) }\end{array}$ \\
\hline European Union (28) & 166,744 & 7,279 & 22,906 & 40.22 \\
\hline Germany & 33,087 & 8,068 & 4,101 & 40.53 \\
\hline France & 25,055 & 7,058 & 3,550 & 39.92 \\
\hline Great Britain & 15,488 & 8,243 & 1,879 & 39.07 \\
\hline Poland & 14,171 & 6,401 & 2,214 & 37.71 \\
\hline The Netherlands & 14,090 & 9,079 & 1,552 & 42.50 \\
\hline Italy & 12,340 & 7,289 & 1,693 & 44.08 \\
\hline Ireland & 7,831 & 5,720 & 1,369 & 39.20 \\
\hline Spain & 7,336 & 8,968 & 818 & 36.83 \\
\hline Denmark & 5,615 & 9,851 & 570 & 42.41 \\
\hline Belgium & 4,178 & 7,898 & 529 & 37.96 \\
\hline Austria & 3,821 & 7,169 & 533 & 38.77 \\
\hline Czechia & 3,162 & 8,808 & 359 & 39.33 \\
\hline Sweden & 2,760 & 8,818 & 313 & 40.85 \\
\hline Finland & 2,398 & 9,083 & 264 & 44.72 \\
\hline United States & 98,688 & 10,546 & 9,358 & 35.86 \\
\hline California & 18,331 & 10,572 & 1,734 & 35.86 \\
\hline Wisconsin & 13,870 & 10,887 & 1,274 & 35.86 \\
\hline Idaho & 6,871 & 11,283 & 609 & 35.86 \\
\hline New York & 6,750 & 10,835 & 623 & 35.86 \\
\hline Texas & 5,830 & 10,856 & 537 & 35.86 \\
\hline Michigan & 5,066 & 11,947 & 424 & 35.86 \\
\hline Pennsylvania & 4,838 & 9,321 & 519 & 35.86 \\
\hline Minnesota & 4,476 & 9,881 & 453 & 35.86 \\
\hline New Mexico & 3,758 & 11,388 & 330 & 35.86 \\
\hline Washington & 3,055 & 11,030 & 277 & 35.86 \\
\hline Brazil & 33,491 & 1,963 & 17,060 & 41.71 \\
\hline China $^{6}$ & 30,640 & 2,563 & 11,955 & 53.87 \\
\hline Russia & 30,611 & 4,492 & 6,815 & 36.58 \\
\hline New Zealand & 21,947 & 4,437 & 4,946 & 35.72 \\
\hline Turkey & 20,037 & 3,161 & 6,338 & 40.22 \\
\hline Canada & 10,228 & 10,519 & 972 & 53.93 \\
\hline Québec & 3,673 & 10,369 & 354 & 53.11 \\
\hline Ontario & 3,377 & 10,432 & 324 & 52.72 \\
\hline British Columbia & 906 & 10,803 & 84 & 58.81 \\
\hline Alberta & 867 & 10,965 & 79 & 55.95 \\
\hline Manitoba & 448 & 10,880 & 41 & 54.14 \\
\hline Saskatchewan & 329 & 11,256 & 29 & 53.74 \\
\hline Nova Scotia & 226 & 10,566 & 21 & 53.17 \\
\hline New Brunswick & 191 & 9,985 & 19 & 53.59 \\
\hline Prince Edward Island & 151 & 10,494 & 14 & 54.02 \\
\hline Newfoundland & 64 & 10,778 & 6 & 70.74 \\
\hline Australia & 9,176 & 6,017 & 1,525 & 34.00 \\
\hline Japan & 7,290 & 8,607 & 847 & 93.15 \\
\hline
\end{tabular}

${ }^{1}$ Values summarized from Rasmussen et al. (2021a).

${ }^{2}$ Canadian production values: CDIC-Average production based on official-supervised records (CDIC, 2019a). US annual production values: USDA ERS-Dairy data-Milk and cow production by state and region (USDA ERS, 2019). All other regions: Dairy sector by country (CLAL, 2019).

${ }^{3}$ Canadian annual per cow production values: CDIC-Average production based on official-supervised records (CDIC, 2019a). US production per cow values: USDA ERS-Dairy data-Milk and cow production by state and region (USDA ERS, 2019). All other regions: Dairy sector by country (CLAL, 2019).

${ }^{4}$ Canadian cattle values: StatCan-Table 32-10-0130-01-Number of cattle, by class and farm type $(\times 1,000)$ (StatCan, 2019b). US cattle values: USDA ERS-Dairy data-Milk and cow production by state and region (USDA ERS, 2019). All other regions: Dairy sector by country (CLAL, 2019).

${ }^{5}$ Turkey: 2018 EU-28. Australian price: Australian dairy industry in focus - 2018 (Dairy Australia, 2019). Canadian values: CDIC-MI011Canadian farm cash receipts from dairying (CDIC, 2019c). All other regions: Dairy sector by country (CLAL, 2019). Converted to 2018 US\$ using IRS.gov-Yearly average currency exchange rates (IRS, 2020).

${ }^{6} 2017$ values. 
Table 2. Region-specific aggregated input variables used in the estimation of the economic premiums associated with the purchase of Mycobacterium avium subspecies paratuberculosis-negative replacement animals ${ }^{1}$

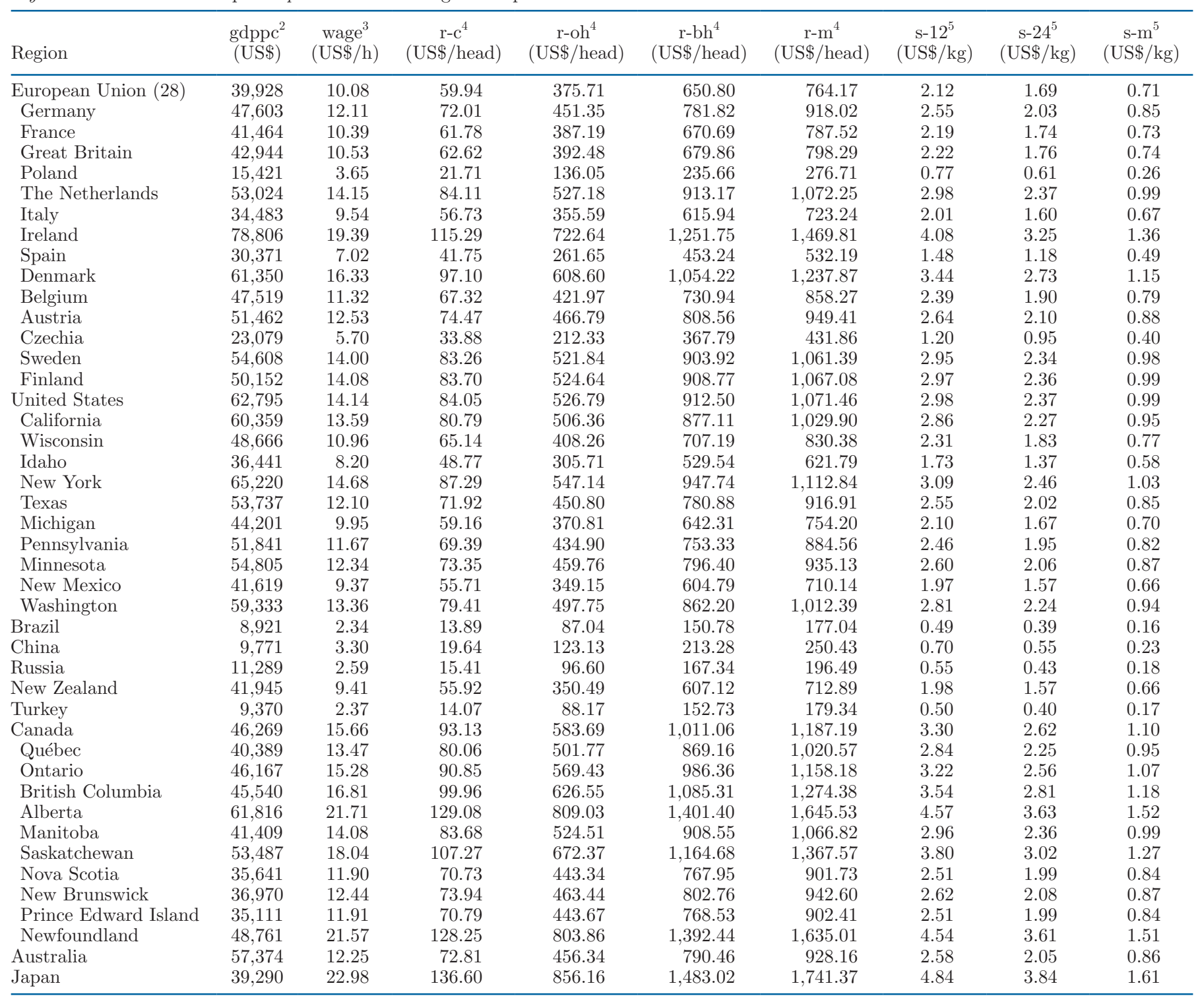

${ }^{1}$ Values summarized from Rasmussen et al. (2021a).

${ }^{2}$ Gross domestic product per capita (gdppc). US gross domestic product per capita by state (BEA, 2019) and Canadian gross domestic product by province (StatCan, 2019c). Converted to US\$ (IRS, 2020). All other regions (World Bank, 2020).

${ }^{3}$ Estimated aggregate dairy wage rate (wage). US 2018 (USDA NASS, 2019). All other regions ( $i$ through $n$ ) calculated using the following formula: wage $_{i}=\frac{\text { wage }_{U S A} \times \text { gdppc }}{i} \times{\text { farm }- \text { gate }_{\text {price }}}_{i}$.

${ }^{4}$ Calf (c), open heifer (oh), bred heifer (bh), and mature cow (m) replacement (r) costs. US replacement prices (USDA, 2020). All other regions

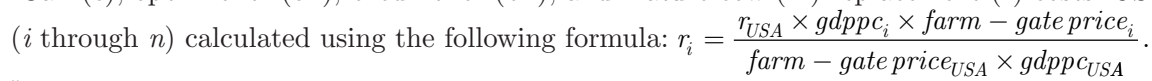

${ }^{5} 0-12$-mo animals (12), 12-24-mo animals (24), and mature cow (m) salvage (s) prices. Canadian salvage prices (StatCan, 2019a). Converted to kilograms at $50.8023 \mathrm{~kg} /$ hundredweight and converted to US\$ (IRS, 2020). All other regions ( $i$ through $n$ ) calculated using the following for-

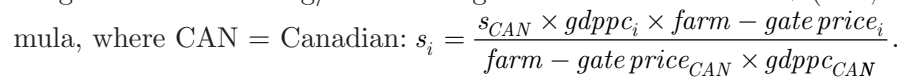

regions and fixed annual production reflective of supply management are presented in Table 6. For MAP-negative herds and in the variable annual production sce- nario, benefits and premiums are generally greater than those estimated for other regions. Ten-year average annual benefits per MAP-negative replacement purchased 
ranged from US\$133 in New Brunswick to US\$197 in Newfoundland and Labrador, with a Canadian average of US\$146. Canadian average values were based on Canadian average input variable values weighted according to provincial dairy cattle head counts. Economic premiums as a percentage of replacement price ranged from $13 \%$ in Alberta to $19 \%$ in Nova Scotia and in Prince Edward Island, with a Canadian average of $15 \%$. When instead estimated with the constraint of fixed annual production, benefits were still generally above those estimated in other regions, but premiums were now below average. Benefits per replacement ranged from US\$67 in Prince Edward Island to US\$126 in Newfoundland and Labrador, with a Canadian average of US $\$ 81$. Economic premiums as a percentage of aggregated replacement prices ranged from $8 \%$ in Alberta and Ontario to $10 \%$ in British Columbia, Manitoba, New Brunswick, Nova Scotia, and Newfoundland and Labrador, with a Canadian average of $9 \%$.

Canadian estimates for MAP-positive herds under both the assumptions of variable annual production and fixed annual production are presented in Table 7 . Ten-year average annual benefits per MAP-negative replacement purchased ranged from US\$118 in New Brunswick to US\$177 in Newfoundland and Labrador, with a Canadian average of US\$131. Economic premiums as a percentage of replacement price ranged from $11 \%$ in Alberta to $16 \%$ in Nova Scotia and in Prince Edward Island, with a Canadian average of $13 \%$. When instead estimated with the constraint of fixed annual production, benefits were still generally above those estimated in other regions, but premiums were below those of other regions. Benefits per replacement ranged from US $\$ 65$ in Prince Edward Island to US $\$ 121$ in Newfoundland and Labrador, with a Canadian average of US\$79. Economic premiums as a percentage of aggregated replacement prices ranged from $8 \%$ in Alberta and Ontario to $9 \%$ in British Columbia, Manitoba, Nova Scotia, and New Brunswick and Labrador with a Canadian average of $8 \%$.

The expected value of aggregated replacement prices, economic benefits, and economic premiums across $\mathrm{Ca}-$ nadian provinces based on $50 \%$ of herds being MAP negative and $50 \%$ of herds being MAP positive are presented in Table 8. In the variable production scenario, benefits ranged from US\$126 in New Brunswick to US $\$ 187$ in Newfoundland and Labrador with a Canadian average of US\$139, whereas premiums ranged from $12 \%$ in Alberta to $18 \%$ in Prince Edward Island with a Canadian average of $14 \%$. In the fixed production scenario, benefits ranged from US\$66 in Prince Edward Island to US\$123 in Newfoundland and Labrador with a Canadian average of US $\$ 80$, whereas premiums ranged from $8 \%$ in Alberta, Saskatchewan, and Ontario 
Table 4. Ten-year aggregated replacement prices (average across mature cows, bred heifers, and open heifers in US\$), annual benefits per Mycobacterium avium subspecies paratuberculosis (MAP)-negative replacement, and economic premiums associated with MAP-negative replacements across major dairy-producing regions in both MAP-negative and MAP-positive herds ${ }^{1}$

\begin{tabular}{|c|c|c|c|c|c|c|}
\hline Region & \multicolumn{3}{|c|}{ MAP-negative herds } & \multicolumn{3}{|c|}{ MAP-positive herds } \\
\hline European Union (28) & 608.18 & 79.29 & 13.04 & 645.69 & 72.76 & 11.27 \\
\hline Germany & 730.62 & 90.22 & 12.35 & 775.68 & 83.39 & 10.75 \\
\hline Poland & 220.23 & 56.20 & 25.52 & 233.81 & 48.30 & 20.66 \\
\hline The Netherlands & 853.37 & 106.17 & 12.44 & 905.99 & 98.04 & 10.82 \\
\hline Italy & 575.61 & 84.01 & 14.60 & 611.10 & 76.03 & 12.44 \\
\hline Ireland & $1,169.78$ & 83.65 & 7.15 & $1,241.91$ & 84.98 & 6.84 \\
\hline Spain & 423.55 & 80.88 & 19.10 & 449.67 & 71.16 & 15.83 \\
\hline Denmark & 985.18 & 116.94 & 11.87 & $1,045.93$ & 108.69 & 10.39 \\
\hline Belgium & 683.07 & 83.15 & 12.17 & 725.19 & 77.01 & 10.62 \\
\hline California & 819.67 & 103.70 & 12.65 & 870.21 & 95.54 & 10.98 \\
\hline Wisconsin & 660.88 & 100.83 & 15.26 & 701.63 & 90.78 & 12.94 \\
\hline Idaho & 494.87 & 98.31 & 19.87 & 525.38 & 86.18 & 16.40 \\
\hline New York & 885.68 & 107.78 & 12.17 & 940.29 & 99.82 & 10.62 \\
\hline Texas & 729.74 & 102.85 & 14.09 & 774.74 & 93.46 & 12.06 \\
\hline Michigan & 600.25 & 106.58 & 17.76 & 637.26 & 94.43 & 14.82 \\
\hline Pennsylvania & 704.00 & 90.83 & 12.90 & 747.40 & 83.46 & 11.17 \\
\hline Minnesota & 744.25 & 96.22 & 12.93 & 790.14 & 88.39 & 11.19 \\
\hline New Mexico & 565.18 & 101.36 & 17.93 & 600.03 & 89.72 & 14.95 \\
\hline Washington & 805.74 & 106.59 & 13.23 & 855.42 & 97.63 & 11.41 \\
\hline Brazil & 140.90 & 21.22 & 15.06 & 149.59 & 19.13 & 12.79 \\
\hline China & 199.31 & 34.54 & 17.33 & 211.60 & 30.67 & 14.50 \\
\hline Russia & 156.38 & 38.47 & 24.60 & 166.02 & 33.14 & 19.96 \\
\hline New Zealand & 567.37 & 50.68 & 8.93 & 602.35 & 49.28 & 8.18 \\
\hline
\end{tabular}

${ }^{1}$ Initial within-herd MAP prevalence of $10 \%$ and a mean herd-level prevalence of $50 \%$ (initial mean prevalence of $5 \%$ among purchased replacements) were assumed. Regions ordered according to total milk production.

${ }^{2}$ Based on the average total number of replacements purchased over the 10-yr horizon and regional aggregated replacement prices across all age groups (Rasmussen et al., 2021a).

to $10 \%$ in Manitoba and Nova Scotia with a Canadian average of $8 \%$.

\section{Sensitivity Analyses}

The sensitivity of the estimated economic premiums in average MAP-negative and MAP-positive dairy herds to a variety of input variables over 10,000 iterations is presented in Figure 1. Premiums associated with MAP-negative replacement purchases were greater in MAP-negative herds compared with their regional MAP-positive counterparts, despite withinherd prevalence being positively related to premiums and the most impactful variable in MAP-positive herds. In both types of herds, herd-level prevalence had a substantial effect and was positively related to the estimated premium. Farm-gate price and production per cow were also identified as impactful variables in both cases, as was the dairy replacement price, particularly for mature cows. However, the replacement price variables were the only variables that were inversely related to the estimated economic premium. The effect of the price of bred (pregnant) heifers was substantial in MAP-negative herds, but like the price of open heifers, not substantial enough to reveal the direction of its relationships to the estimated premiums in MAPpositive herds. However, logically all replacement prices must be negatively related to the estimated economic premium in both sets of herds because the premium is inversely related to the aggregated replacement price. 
Table 5. Average herds (50\% infected and 50\% negative): 10-yr aggregated replacement prices (average across mature cows, bred heifers, and open heifers in US\$), annual benefits per Mycobacterium avium subspecies paratuberculosis (MAP)-negative replacement, and economic premiums associated with MAP-negative replacements across major dairy-producing regions ${ }^{1}$

\begin{tabular}{|c|c|c|c|}
\hline Region & $\begin{array}{c}\text { Aggregated } \\
\text { replacement } \\
\text { price }^{2}(\mathrm{US} \$ / \text { head })\end{array}$ & $\begin{array}{l}\text { Benefits per } \\
\text { MAP-negative replacement } \\
\text { (US } \$ \text { /head per year) }\end{array}$ & $\begin{array}{l}\text { Economic premium } \\
\text { (\% of replacement } \\
\text { price) }\end{array}$ \\
\hline European Union (28) & 626.93 & 76.02 & 12.13 \\
\hline Germany & 753.15 & 86.81 & 11.53 \\
\hline France & 646.09 & 74.69 & 11.56 \\
\hline Great Britain & 654.92 & 82.37 & 12.58 \\
\hline Poland & 227.02 & 52.25 & 23.02 \\
\hline The Netherlands & 879.68 & 102.10 & 11.61 \\
\hline Italy & 593.35 & 80.02 & 13.49 \\
\hline Ireland & $1,205.84$ & 84.32 & 6.99 \\
\hline Spain & 436.61 & 76.02 & 17.41 \\
\hline Denmark & $1,015.56$ & 112.82 & 11.11 \\
\hline Belgium & 704.13 & 80.08 & 11.37 \\
\hline Austria & 778.91 & 78.78 & 10.11 \\
\hline Czechia & 354.30 & 76.01 & 21.45 \\
\hline Sweden & 870.77 & 97.10 & 11.15 \\
\hline Finland & 875.44 & 105.67 & 12.07 \\
\hline United States & 879.03 & 100.68 & 11.45 \\
\hline California & 844.94 & 99.62 & 11.79 \\
\hline Wisconsin & 681.25 & 95.81 & 14.06 \\
\hline Idaho & 510.12 & 92.25 & 18.08 \\
\hline New York & 912.99 & 103.80 & 11.37 \\
\hline Texas & 752.24 & 98.15 & 13.05 \\
\hline Michigan & 618.75 & 100.50 & 16.24 \\
\hline Pennsylvania & 725.70 & 87.15 & 12.01 \\
\hline Minnesota & 767.19 & 92.31 & 12.03 \\
\hline New Mexico & 582.61 & 95.54 & 16.40 \\
\hline Washington & 830.58 & 102.11 & 12.29 \\
\hline Brazil & 145.25 & 20.18 & 13.89 \\
\hline China & 205.46 & 32.60 & 15.87 \\
\hline Russia & 161.20 & 35.81 & 22.21 \\
\hline New Zealand & 584.86 & 49.98 & 8.55 \\
\hline Turkey & 147.13 & 28.52 & 19.38 \\
\hline Australia & 761.47 & 64.75 & 8.50 \\
\hline Japan & $1,428.64$ & 197.80 & 13.85 \\
\hline
\end{tabular}

${ }^{1}$ An initial within-herd MAP prevalence of $10 \%$ and a mean herd-level prevalence of $50 \%$ (initial mean prevalence of $5 \%$ among purchased replacements) were assumed. Regions ordered according to total milk production. ${ }^{2}$ Based on the average total number of replacements purchased over the 10-yr horizon and regional aggregated replacement prices across all age groups (Rasmussen et al., 2021a).

Detailed sensitivity analyses for the Markovian herd model itself are available in Rasmussen et al. (2021a).

\section{DISCUSSION}

The estimated benefits to MAP-negative herds were greater than the estimated benefits to MAP-positive herds despite the positive relationship between withinherd prevalence and the economic premiums associated with MAP-negative replacements. This surprising and somewhat counterintuitive finding suggests that the greatest benefits from JD control are associated with the prevention of MAP infection at the herd level; although economic losses due to MAP infection increase with within-herd prevalence, those losses are primarily driven by the initial periods as the herd transitions from MAP negative to MAP positive. With assumed values of an initial within-herd MAP infection prevalence of $10 \%$ and a herd-level prevalence of $50 \%$ for all regions, region-specific economic variables such as the farm-gate price of milk, annual production per cow, and the aggregated price of dairy replacements were responsible for the majority of the variation in the expected value of economic premiums across regions (Table 5). When excluding Canada due to the unique market conditions that arise due to its supply management system, the greatest economic premiums were observed in regions characterized by below-average aggregated replacement prices and on-average farm-gate prices, such as Czechia, Spain, Poland, Russia, and Turkey. In these regions, the expected value of aggregated replacement prices ranged from US $\$ 147$ to US $\$ 437$ per animal purchased compared with the revenue-weighted average price of US\$621, whereas farm-gate prices (Table 1) ranged from 
US $\$ 37$ to US\$40 compared with the revenue-weighted average price of US\$40. Conversely, the smallest economic premiums were observed in regions characterized by on- or above-average replacement prices and belowaverage production per cow such as Australia, Ireland, and New Zealand. In these regions, replacement prices ranged from US $\$ 585$ to US $\$ 1,206$ per animal, whereas annual production per cow ranged from 4,437 to 6,017 $\mathrm{kg}$, compared with the weighted average of $7,302 \mathrm{~kg}$.

Although the general method used to estimate the premiums associated with MAP-negative replacement purchases is appropriate for most major dairyproducing regions, the Canadian dairy sector requires particular attention, as discussed in Rasmussen et al. (2021a,b). Farm-gate milk prices in Canada are determined through a complex process requiring negotiation across regional milk pools and provincial milk boards, incorporating milk pool cost and revenue data, cost of production data from the Canadian Dairy Commission, production quotas, and harmonized pricing. These planned and controlled domestic production levels, cost-of-production-based pricing of fluid milk, and import controls are designed to insulate Canadian producers from competitive forces both domestic and foreign in an overarching supply management system. If the Canadian dairy sector is modeled as a strict annually fixed production system, there are 2 consequences for this study: (1) production losses can no longer be quantified as the value of forgone milk sales since producers cannot be financially compensated for production in excess of their production quota, and (2) Canadian dairy producers receive an above-average farm-gate milk price, which is the highest among countries modeled (aside from Japan which subsidizes dairy production at particularly high rates) and much higher than the price received by dairy producer in the United States, Canada's most analogous counterpart. The higher farm-gate price in Canada results in a greater valuation of milk production losses associated with MAP infection (Rasmussen et al., 2021a) and therefore greater economic benefits associated with the purchase of MAP-negative replacements in Canada. While the differences in estimated benefits across the 2 neighboring dairy sectors are partially attributable to differences in technical and allocative efficiencies, which are not addressed by this study, the effects of supply management in Canadian dairy are addressed, at least in as much as Canadian market prices capture benefits from being part of a supply-managed agricultural industry. To reflect the constraint of fixed annual production levels for Canadian producers, milk production losses were also quantified as the cost of having additional,

Table 6. Negative Canadian herds: 10-yr aggregated replacement prices (average across mature cows, bred heifers, and open heifers in US\$), benefits per Mycobacterium avium subspecies paratuberculosis (MAP)-negative replacement, and economic premiums associated with MAPnegative replacements across Canadian provinces for MAP-negative herds in both variable production and fixed production scenarios ${ }^{1}$

\begin{tabular}{|c|c|c|c|c|c|c|}
\hline Region & $\begin{array}{c}\text { Variable costs }{ }^{2} \\
\text { (US } \$ / \text { cow } \\
\text { per year) }\end{array}$ & $\begin{array}{c}\text { Aggregated } \\
\text { replacement } \\
\text { price } \\
(\mathrm{US} \$ / \text { head })\end{array}$ & \multicolumn{2}{|c|}{ Variable production } & \multicolumn{2}{|c|}{ Fixed production } \\
\hline Canada & $2,546.33$ & 944.85 & 146.00 & 15.45 & 81.07 & 8.39 \\
\hline British Columbia & $3,294.82$ & $1,014.24$ & 162.09 & 15.98 & 98.12 & 7.81 \\
\hline Alberta & $3,194.58$ & $1,309.63$ & 167.27 & 12.77 & 105.76 & 6.05 \\
\hline Manitoba & $3,099.13$ & 849.05 & 147.31 & 17.35 & 88.87 & 9.33 \\
\hline Saskatchewan & $2,863.76$ & $1,088.41$ & 158.31 & 14.55 & 92.02 & 7.28 \\
\hline Nova Scotia & $2,585.91$ & 717.66 & 137.50 & 19.16 & 74.45 & 11.04 \\
\hline New Brunswick & $2,534.25$ & 750.19 & 133.12 & 17.74 & 74.49 & 10.56 \\
\hline Prince Edward Island & $2,204.63$ & 718.20 & 138.53 & 19.29 & 66.94 & 11.03 \\
\hline
\end{tabular}

${ }^{1}$ In the fixed production scenario, production losses due to MAP infection are measured as the additional variable costs per cow due to a greater number of cows being required to maintain production levels. An initial within-herd MAP prevalence of $10 \%$ and a mean herd-level prevalence of 50\% (initial mean prevalence of 5\% among purchased replacements) were assumed. Regions ordered according to total milk production.

${ }^{2}$ StatCan-Table 32-10-0136-01 Farm operating revenues and expenses, annual (StatCan, 2019a). Sum of "Total livestock expenses" and "Total variable livestock expenditures added to salaries and wages, including benefits related to employee salaries for average dairy farms across all revenue levels." Total per farm divided by number of cows per farm. Number of cows per farm obtained by number of cattle divided by number of farms: CDIC-Number of farms with shipments of milk by province (CDIC, 2019b). Number of cattle: StatCan-Table 32-10-0130-01-Number of cattle, by class and farm type (StatCan, 2019b).

${ }^{3}$ Based on the average total number of replacements purchased across all age groups and regional aggregated replacement prices (Rasmussen et al., 2021a). 
Table 7. Infected Canadian herds: 10-yr aggregated replacement prices (average across mature cows, bred heifers, and open heifers in US\$), benefits per Mycobacterium avium subspecies paratuberculosis (MAP)-negative replacement, and economic premiums associated with MAPnegative replacements across Canadian provinces for MAP-positive herds in both variable production and fixed production scenarios ${ }^{1}$

\begin{tabular}{|c|c|c|c|c|c|c|}
\hline Region & $\begin{array}{c}\text { Variable costs }{ }^{2} \\
\text { (US\$/cow } \\
\text { per year) }\end{array}$ & $\begin{array}{c}\text { Aggregated } \\
\text { replacement } \\
\text { price }^{3} \\
\text { (US\$/head) }\end{array}$ & \multicolumn{2}{|c|}{ Variable production } & \multicolumn{2}{|c|}{ Fixed production } \\
\hline Canada & $2,546.33$ & $1,003.11$ & 131.26 & 13.09 & 79.42 & 7.92 \\
\hline Alberta & $3,194.58$ & $1,390.38$ & 153.91 & 11.07 & 104.81 & 7.54 \\
\hline Manitoba & $3,099.13$ & 901.40 & 130.82 & 14.51 & 84.16 & 9.34 \\
\hline Saskatchewan & $2,863.76$ & $1,155.52$ & 143.32 & 12.40 & 90.40 & 7.82 \\
\hline Nova Scotia & $2,585.91$ & 761.91 & 120.94 & 15.87 & 70.60 & 9.27 \\
\hline New Brunswick & $2,534.25$ & 796.45 & 117.95 & 14.81 & 71.14 & 8.93 \\
\hline $\begin{array}{l}\text { Prince Edward } \\
\text { Island }\end{array}$ & $2,204.63$ & 762.48 & 121.77 & 15.97 & 64.61 & 8.47 \\
\hline
\end{tabular}

${ }^{1}$ An initial within-herd MAP prevalence of $10 \%$ and a mean herd-level prevalence of $50 \%$ (initial mean prevalence of $5 \%$ among purchased replacements) were assumed. Regions ordered according to total milk production. In the fixed production scenario, production losses due to MAP infection are measured as the additional variable costs per cow due to a greater number of cows being required to maintain production levels. Regions ordered according to total milk production.

${ }^{2}$ StatCan-Table 32-10-0136-01 Farm operating revenues and expenses, annual (StatCan, 2019a). Sum of "Total livestock expenses" and "Total variable livestock expenditures added to salaries and wages, including benefits related to employee salaries for average dairy farms across all revenue levels." Total per farm divided by number of cows per farm. Number of cows per farm obtained by number of cattle divided by number of farms: CDIC-Number of farms with shipments of milk by province (CDIC, 2019b). Number of cattle: StatCan-Table 32-10-0130-01-Number of cattle, by class and farm type (StatCan, 2019b).

${ }^{3}$ Based on the average total number of replacements purchased across all age groups and regional aggregated replacement prices (Rasmussen et al., 2021a).

less productive MAP-positive cows to maintain a fixed level of production over the 10-yr horizon.

Under the fixed production assumption, the expected value of estimated benefits per MAP-negative replacement purchased in average Canadian dairy herds (Table 8) decreased from the variable production estimate of US\$139 per MAP-negative replacement purchased (a premium of $14 \%$ ), to US $\$ 80$ (a premium of $8 \%$ ). Although overall annual production and farm-gate prices in Canada are predetermined and producers are only compensated for the milk produced within their production quota, there is still competition among producers for additional quota (as well as other inputs including land and labor). Overall milk production generally increases year-on-year (CDIC, 2019a) and producers trade quota through a quota exchange market; more profitable producers purchase quota from less profitable ones to increase their production capacities. Partly due to this competition, the number of Canadian dairy herds has steadily decreased while the size of herds has increased (CDIC, 2019b); therefore, producers operate somewhere in between a fixed production and a variable production environment, and the true benefits associated with MAP-negative replacement purchases in
Canadian dairy herds likely lie somewhere in between the 2 estimates, or between US $\$ 80$ and US\$139 per replacement purchased.

At the herd level, for a single producer to become a reliable source of MAP-negative replacements and capture some of these potential trade benefits, there are several requirements: (1) more effective JD control practices must be developed, (2) more sensitive diagnostic tools must be developed, both for their complementary role within an effective control program and also to provide confidence among prospective buyers, (3) the economic value of MAP-negative replacements must recognized, and (4) prospective buyers must be willing to pay a premium for a verified MAP-negative replacement. While research into new control practices and diagnostic tools is ongoing and the necessary components of an effective JD control program are being developed, the latter 2 conditions are largely dependent on the information available to dairy producers. Studies such as this one, where the potential premiums associated with MAP-negative replacement purchases are estimated across major dairy-producing regions, play an important role, but there is also a need to further incentivize producers to invest in JD control in an effort 
to guarantee access to the potential economic benefits associated with being recognized as a MAP-negative dairy herd.

The creation of a futures market for MAP-negative replacement animals, not unlike the Intercontinental Exchange (ICE) used for canola or the Minneapolis Grain Exchange (MGEX) used for wheat, could potentially help producers access these economic premiums. Although futures markets provide flexibility for market participants, their main benefit, particularly for agricultural goods, come from their "risk-transfer" and "price-discovery" functions (Silber, 1985); they provide an efficient mechanism for hedging and a trusted forum for establishing and disseminating price information. In the case of a futures market for MAP-negative dairy replacements, registered and verified MAP-negative herds would sell replacements at an agreed upon price for some future delivery date to a clearing organization, which would then sell the replacements to dairy herds looking to either decrease the risk of MAP contagion within their herds, decrease MAP prevalence within their herds, or expand their operations while remaining verified MAP-negative sellers within the futures market.
There are, however, incentives for dairy producers to invest in JD control aside from directly estimable economic benefits and potential access to domestic and international trade premiums. From a herd-health perspective, although JD control remains a minor priority for dairy producers relative to more easily addressable diseases and conditions such as mastitis, research into interactions between MAP and other pathogens affecting dairy cows is still developing. Higher incidences of and higher culling rates due to mastitis have been observed in MAP-positive herds (Diéguez et al., 2008; Arrazuría et al., 2014), and a higher incidence of clinical mastitis has been observed in MAP-positive cows (Rossi et al., 2017). It has also been suggested that JD control will likely reduce the incidence of similarly transmitted infections in calves such as rotavirus and coronavirus, Escherichia coli, Cryptosporidium parvum, Cryptosporidium bovis, and Salmonella spp. (Barkema et al., 2018). It is also important to recognize that the model assumes replacement animals supplied to the market are representative of the overall population in terms of both productivity and animal-level prevalence of MAP infection. However, given the detrimental effects of MAP infection on key production charac-

Table 8. Average Canadian herds (50\% infected and 50\% negative): expected values for 10-yr aggregated replacement prices (average across mature cows, bred heifers, and open heifers in US\$), benefits per Mycobacterium avium subspecies paratuberculosis (MAP)-negative replacement, and economic premiums associated with MAP-negative replacements across Canadian provinces in both variable production and fixed production scenarios

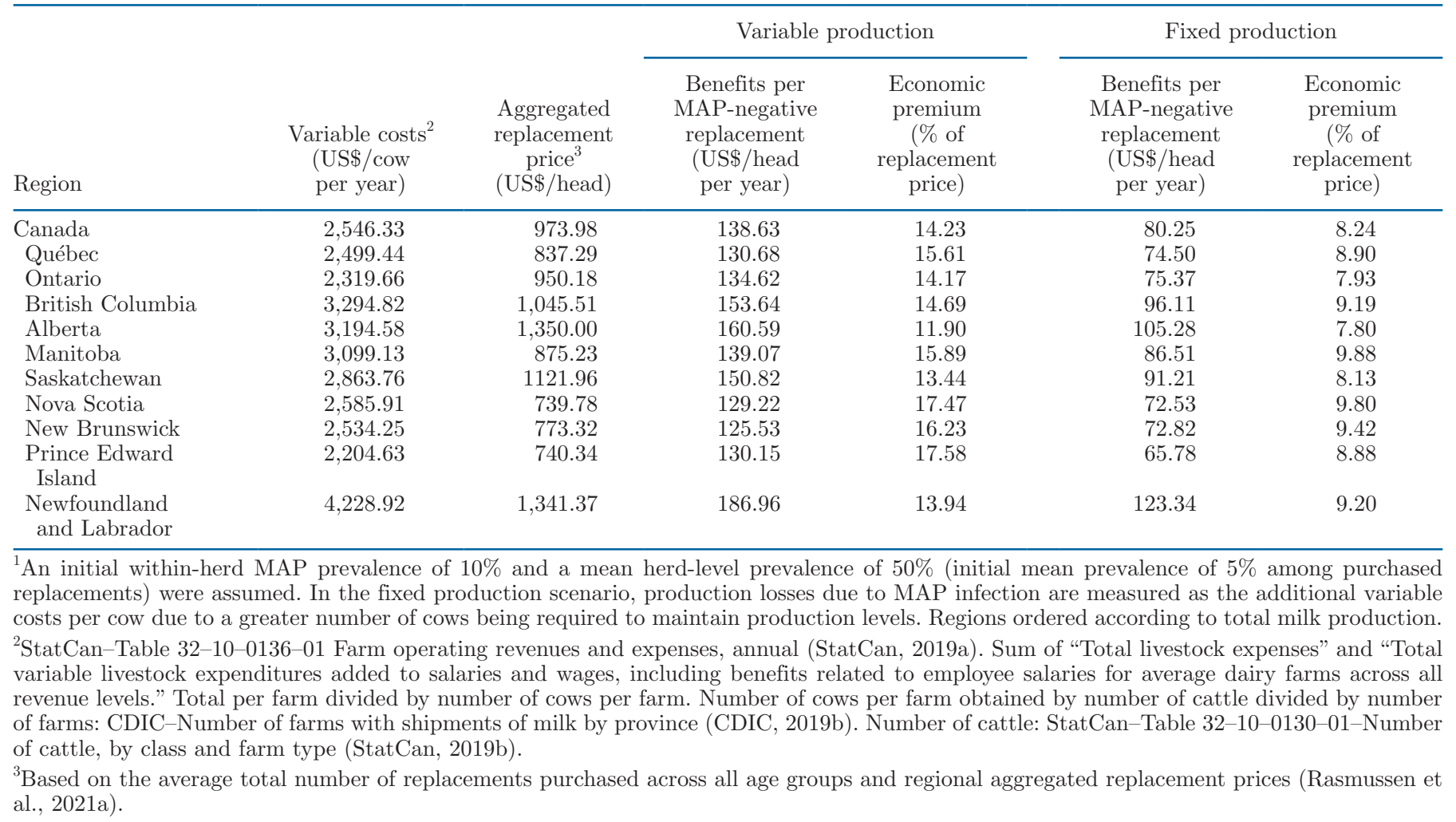



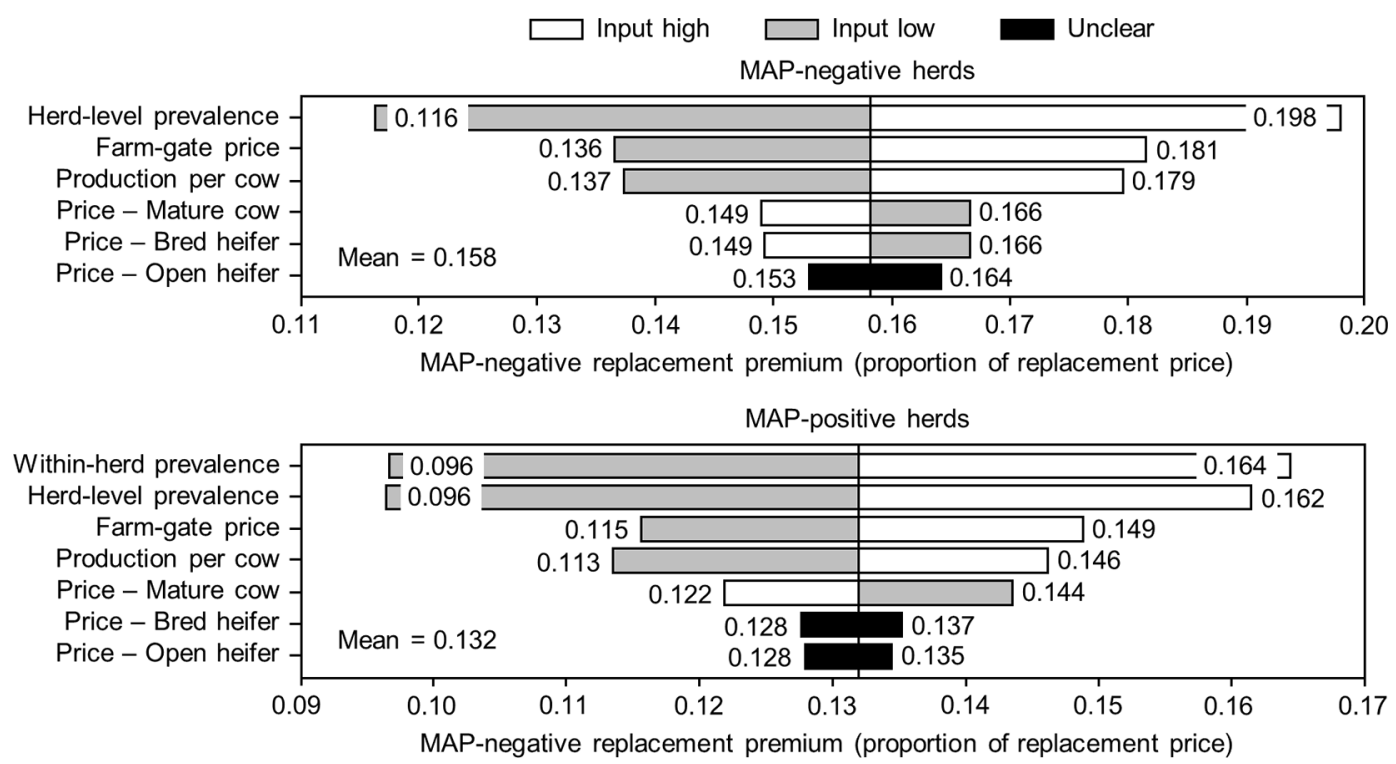

Figure 1. Sensitivity of estimated economic premiums associated with Mycobacterium avium ssp. paratuberculosis (MAP)-negative replacements in average dairy herds (as modeled) to a range of input variables (10,000 iterations) in both MAP-negative and MAP-positive herds. An initial mean value of $10 \%$ within-herd prevalence in MAP-positive herds, $50 \%$ herd-level prevalence, and a $5 \%$ MAP-infection prevalence among purchased replacements were assumed. The color of the sensitivity bars indicates the direction of the relationship between the variable and estimated losses (gray indicates the effect of variable values below their mean value, white indicates the effect of values above their mean, and black indicates that the effect is unclear).

teristics (e.g., reduced yield, increased mortality, and so on), it is possible that producers would retain the animals with the most desirable characteristics while supplying those with the least desirable characteristics to the replacement market. In other words, the prevalence of MAP infection among replacement animals could exceed the prevalence among animals in the population, and the benefits accrued from purchasing MAP-negative replacement animals may therefore be underestimated in this model. On the other hand, this model may be overestimating the net economic costs of increased culling due to MAP infection because potential benefits associated with having a greater proportion of younger animals in the herd were not considered. For example, age-related conditions such as reduced fertility and increased risks of mastitis and lameness are all potential sources of economic losses that could be somewhat offset by an increased cowculling rate.

\section{CONCLUSIONS}

It was estimated that significant economic benefits can be accrued through the purchase of MAP-negative dairy replacements as opposed to replacements with unknown MAP infection status. Greater premiums were observed in MAP-negative herds relative to MAP-positive herds despite within-herd prevalence be- ing positively related to the estimated premium. This suggests that although the benefits associated with the purchase of MAP-negative replacements increase with within-herd prevalence, the greatest benefits are captured by herds that avoid infection altogether. Assuming a regional cow-level MAP infection prevalence of $5 \%$ among replacement animals, a revenue-weighted average benefit of US\$76 per MAP-negative replacement was estimated, equivalent to a premium of $13 \%$ of average aggregated replacement prices across both infected and uninfected dairy herds in major dairyproducing regions. For Canadian dairy herds, it was estimated that the economic benefits range from US $\$ 80$ to US\$139 per MAP-negative replacement, or 8 to $14 \%$ of average aggregate replacement prices. Although the potential domestic and international trade benefits of JD control were not estimated, this research suggests that MAP-negative replacements have significant additional value, and that given the dissemination of accurate pricing information and an organized market, this value could be captured, at least in part, by herds that successfully control JD.

\section{ACKNOWLEDGMENTS}

This research was supported by Genome Canada (Ottawa, ON), Genome Prairie (Saskatoon, SK and Winnipeg, MB), and Genome British Columbia (Van- 
couver, BC; 225RVA). The authors have not stated any conflicts of interest.

\section{REFERENCES}

Arrazuría, R., I. Arnaiz, R. Fouz, C. Calvo, C. Eiras, and F. J. Diéguez. 2014. Association between Mycobacterium avium subsp. paratuberculosis infection and culling in dairy cattle herds. Arch. Med. Vet. 46:39-44. https://doi.org/10.4067/S0301-732X2014000100006.

Barkema, H. W., K. Orsel, S. S. Nielsen, A. P. Koets, V. P. M. G. Rutten, J. P. Bannantine, G. P. Keefe, D. F. Kelton, S. J. Wells, R. J. Whittington, C. G. Mackintosh, E. J. Manning, M. F. Weber, C. Heuer, T. L. Forde, C. Ritter, S. Roche, C. S. Corbett, R. Wolf, P. J. Griebel, J. P. Kastelic, and J. De Buck. 2018. Knowledge gaps that hamper prevention and control of Mycobacterium avium subspecies paratuberculosis infection. Transbound. Emerg. Dis. 65(Suppl. 1):125-148. https://doi.org/10.1111/tbed.12723.

BEA. 2019. Regional Economic Accounts - SAGDP Tables: Annual GDP by State. Accessed Jan. 13, 2020. https://www.bea.gov/ data/gdp/gdp-state.

Benedictus, G., A. A. Dijkhuizen, and J. Stelwagen. 1985. (Economic losses to farms due to paratuberculosis in cattle). Tijdschr. Diergeneeskd. 110:310-319. (In Dutch.)

CDIC. 2019a. D037-3 - Average production by province. Accessed Jan. 18, 2021. https://aimis-simia-cdic-ccil.agr.gc.ca/rp/index-eng .cfm?action $=\mathrm{pR} \& \mathrm{r}=215 \& \mathrm{pdctc}=$.

CDIC. 2019b. D056 - Number of farms with shipments of milk by province. Accessed Jan. 18, 2021. https://aimis-simia-cdic-ccil.agr .gc.ca/rp/index-eng.cfm?action $=\mathrm{pR} \& \mathrm{r}=220 \&$ pdctc $=$.

CDIC. 2019c. MI011 - Canadian farm cash receipts from dairying. Accessed Jan. 19, 2021. https://aimis-simia-cdic-ccil.agr.gc.ca/rp/ index-eng. .fm?action $=\mathrm{pR} \& \mathrm{r}=272 \& \mathrm{pdctc}=$.

CLAL. 2019. Dairy sector by country. Accessed Sep. 15, 2020. https: //www.clal.it/en/.

Dairy Australia. 2019. Dairy in Focus - 2018. Accessed Jul. 18, 2021. https://cdn-prod.dairyaustralia.com.au/-/media/ project/dairy-australia-sites/national-home/resources/2020/ 07/09/in-focus-report-2019/in-focus-report-2019.pdf?rev= 4672892dc1664acc8e28cdd6b5930940.

Diéguez, F. J., I. Arnaiz, M. L. Sanjuán, M. J. Vilar, and E. Yus. 2008. Management practices associated with Mycobacterium avium subspecies paratuberculosis infection and the effects of the infection on dairy herds. Vet. Rec. 162:614-617. https://doi.org/10.1136/vr .162 .19 .614 .

Donaghy, J., M. Keyser, J. Johnston, F. P. Cilliers, P. A. Gouws, and M. T. Rowe. 2009. Inactivation of Mycobacterium avium ssp. paratuberculosis in milk by UV treatment. Lett. Appl. Microbiol. 49:217-221. https://doi.org/10.1111/j.1472-765X.2009.02644.x.

Fecteau, M. E., and R. H. Whitlock. 2010. Paratuberculosis in cattle. Pages 144-156 in Paratuberculosis: Organism, Disease, Control. M. A. Behr and D. M. Collins, ed. CABI.

Garcia, A. B., and L. Shalloo. 2015. Invited review: The economic impact and control of paratuberculosis in cattle. J. Dairy Sci. 98:5019-5039. https://doi.org/10.3168/jds.2014-9241.

Groenendaal, H., M. Nielen, and J. W. Hesselink. 2003. Development of the Dutch Johne's disease control program supported by a simulation model. Prev. Vet. Med. 60:69-90. https://doi.org/10.1016/ S0167-5877(03)00083-7.

Groenendaal, H., M. Nielen, A. W. Jalvingh, S. H. Horst, D. T. Galligan, and J. W. Hesselink. 2002. A simulation of Johne's disease control. Prev. Vet. Med. 54:225-245. https://doi.org/10.1016/ S0167-5877(02)00027-2.

Groenendaal, H., F. J. Zagmutt, E. A. Patton, and S. J. Wells. 2015. Cost-benefit analysis of vaccination against Mycobacterium avium ssp. paratuberculosis in dairy cattle, given its cross-reactivity with tuberculosis tests. J. Dairy Sci. 98:6070-6084. https://doi.org/10 $.3168 /$ jds.2014-8914.

IRS. 2020. Yearly average currency exchange rates. Accessed Jan. 8, 2021. https://www.irs.gov/individuals/international-taxpayers/ yearly-average-currency-exchange-rates.
Kirkeby, C., K. Græsbøll, S. S. Nielsen, L. E. Christiansen, N. Toft, E. Rattenborg, and T. Halasa. 2016. Simulating the epidemiological and economic impact of paratuberculosis control actions in dairy cattle. Front. Vet. Sci. 3:90. https://doi.org/10.3389/fvets .2016 .00090 .

Kudahl, A. B., and S. S. Nielsen. 2009. Effect of paratuberculosis on slaughter weight and slaughter value of dairy cows. J. Dairy Sci. 92:4340-4346. https://doi.org/10.3168/jds.2009-2039.

Kudahl, A. B., S. Østergaard, J. T. Sørensen, and S. S. Nielsen. 2007. A stochastic model simulating paratuberculosis in a dairy herd. Prev. Vet. Med. 78:97-117. https://doi.org/10.1016/j.prevetmed .2006.05.015.

Lombard, J. E., F. B. Garry, B. J. McCluskey, and B. A. Wagner. 2005. Risk of removal and effects on milk production associated with paratuberculosis status in dairy cows. J. Am. Vet. Med. Assoc. 227:1975-1981. https://doi.org/10.2460/javma.2005.227.1975.

Manning, E. J., and M. T. Collins. 2001. Mycobacterium avium subsp. paratuberculosis: pathogen, pathogenesis and diagnosis. Rev. Sci. Tech. 20:133-150.

McAloon, C. G., P. Whyte, S. J. More, M. J. Green, L. O'Grady, A. Garcia, and M. L. Doherty. 2016. The effect of paratuberculosis on milk yield - A systematic review and meta-analysis. J. Dairy Sci. 99:1449-1460. https://doi.org/10.3168/jds.2015-10156.

OMAFRA. 2020. Culling decisions: Dairy cows. Accessed Jan. 8, 2021. http://www.omafra.gov.on.ca/english/livestock/dairy/facts/ cullcowwelfare.htm\#: : text=Trends $\% 20$ in $\%$ 20culling\%20and $\% 20$ markets,low $\% 20$ milk\%20production $\% 20(16 \% 25)$.

Ott, S. L., S. J. Wells, and B. A. Wagner. 1999. Herd-level economic losses associated with Johne's disease on US dairy operations. Prev. Vet. Med. 40:179-192. https://doi.org/10.1016/S0167 $-5877(99) 00037-9$.

Pillars, R. B., D. L. Grooms, C. A. Wolf, and J. B. Kaneene. 2009 Economic evaluation of Johne's disease control programs implemented on six Michigan dairy farms. Prev. Vet. Med. 90:223-232. https://doi.org/10.1016/j.prevetmed.2009.04.009.

Raizman, E. A., J. P. Fetrow, and S. J. Wells. 2009. Loss of income from cows shedding Mycobacterium avium subspecies paratuberculosis prior to calving compared with cows not shedding the organism on two Minnesota dairy farms. J. Dairy Sci. 92:4929-4936. https://doi.org/10.3168/jds.2009-2133.

Rasmussen, P., H. W. Barkema, and D. C. Hall. 2021b. Effectiveness and economic viability of Johne's disease (paratuberculosis) control practices in dairy herds. Front. Vet. Sci. 7:614727. https://doi .org/10.3389/fvets.2020.614727.

Rasmussen, P., H. W. Barkema, S. Mason, E. Beaulieu, and D. C. Hall. 2021a. Economic losses due to Johne's disease (paratuberculosis) in dairy cattle. J. Dairy Sci. 104:3123-3143. https://doi.org/ 10.3168/jds.2020-19381.

Rossi, G., Y. T. Grohn, Y. H. Schukken, and R. L. Smith. 2017. The effect of Mycobacterium avium ssp. paratuberculosis infection on clinical mastitis occurrence in dairy cows. J. Dairy Sci. 100:74467454. https://doi.org/10.3168/jds.2017-12721.

Shephard, R. W., S. H. Williams, and S. D. Beckett. 2016. Farm economic impacts of bovine Johne's disease in endemically infected Australian dairy herds. Aust. Vet. J. 94:232-239. https://doi.org/ 10.1111/avj.12455.

Silber, W. L. 1985. The economic role of financial futures. Pages 83114 in Futures Markets: Their Economic Role. A. E. Peck, ed. American Enterprise Institute for Public Policy Research.

Smith, R. L., M. A. Al-Mamun, and Y. T. Gröhn. 2017. Economic consequences of paratuberculosis control in dairy cattle: A stochastic modeling study. Prev. Vet. Med. 138:17-27. https://doi.org/10 $.1016 /$ j.prevetmed.2017.01.007.

StatCan. 2019a. Table 32-10-0136-01 Farm operating revenues and expenses, annual. Accessed Aug. 16, 2021. https://www150 .statcan.gc.ca/t1/tbl1/en/tv.action?pid $=3210013601$.

StatCan. 2019b. Table 32-10-0130-01 Number of cattle, by class and farm type $(\times 1,000)$. Accessed Aug. 16, 2021. https://www150 .statcan.gc.ca/t1/tbl1/en/tv.action?pid $=3210013001$.

StatCan. 2019c. Table 36-10-0222-01 Gross domestic product, expenditure-based, provincial and territorial, annual $(\times 1,000,000)$. Ac- 
cessed Nov. 12, 2021. https://www150.statcan.gc.ca/t1/tbl1/en/tv action?pid $=3610022201$

Tiwari, A., J. A. VanLeeuwen, I. R. Dohoo, G. P. Keefe, and A. Weersink. 2008. Estimate of the direct production losses in Canadian dairy herds with subclinical Mycobacterium avium subspecies paratuberculosis infection. Can. Vet. J. 49:569-576.

USDA. 2020. National dairy comprehensive report - Monthly 02/29/2020. Accessed Jul. 19, 2021. https://www.ams.usda.gov/ mnreports/lsmdairycomp.pdf.

USDA ERS. 2019. Dairy data-Milk and cow production by state and region (Annual). Accessed Jul. 19, 2021. https://www.ers.usda .gov/data-products/dairy-data.aspx.

USDA NASS. 2019. Farm labor - 05/30/2019. Accessed Jul. 19 2021. https://www.nass.usda.gov/Publications/Todays_Reports/ reports/fmla0519.pdf.

Van Biert, P. 2019. Economics of milk production in Alberta, 2018: The dairy cost study. Accessed Jul. 19, 2021. https://open.alberta ca/dataset/abca66b6-d117-4ee2-8615-248fcb53262c/resource/ b43613f3-6128-407e-aa85-b7504e0f0907/download/economics-of -milk-production-2018.pdf.
Whittington, R. J., D. J. Marshall, P. J. Nicholls, I. B. Marsh, and L. A. Reddacliff. 2004. Survival and dormancy of Mycobacterium avium subsp. paratuberculosis in the environment. Appl. Environ. Microbiol. 70:2989-3004. https://doi.org/10.1128/AEM.70.5.2989 -3004.2004 .

World Bank. 2020. GDP per capita (current US\$). Accessed Jul. 19 2020. https://data.worldbank.org/indicator/NY.GDP.PCAP.CD.

\section{ORCIDS}

Philip Rasmussen @ https://orcid.org/0000-0002-1936-7254

Herman W. Barkema ํ https://orcid.org/0000-0002-9678-8378

Eugene Beaulieu 주 https://orcid.org/0000-0001-9334-5814

Steve Mason ๑ https://orcid.org/0000-0003-4011-9973

David C. Hall @ https://orcid.org/0000-0002-6622-1848 